\title{
Regeneração in vitro de anteras de arroz irrigado (Oryza sativa L.) e mapeamento de QTL associado
}

\author{
In vitro regeneration of irrigated rice (Oryza sativa $L_{\text {. }}$ ) anthers and detection of associated QTL
}

\author{
Sérgio Dias Lannes ${ }^{1}$ Paulo Dejalma Zimmer ${ }^{2}$ Antonio Costa de Oliveira ${ }^{3}$ Fernando Irajá \\ Félix de Carvalho ${ }^{3}$ Eduardo Alano Vieira ${ }^{4}$ Ariano Martins de Magalhães Junior ${ }^{4}$ \\ Maurício Marini Kopp ${ }^{1}$ Fábio Almeida de Freitas ${ }^{5}$
}

RESUMO

A baixa taxa de regeneração in vitro de alguns cultivares de arroz da subespécie indica limita a utilização de técnicas de cultura de anteras como ferramenta para o desenvolvimento de novos cultivares. A identificação de regiões genômicas associadas à formação de calos e regeneração de plantas, a partir do cultivo de anteras, poderá permitir a transferência do caráter por seleção assistida. Duas populações de retrocruzamento foram utilizadas para o mapeamento genético e estudo destes caracteres, sendo Taipei 309// BRS 7 "Taim"/Taipei 309 (53 genótipos) e BRS 7 "Taim"// BRS 7 "Taim"/Taipei 309 (74 genótipos). Duzentas anteras imaturas de cada genótipo utilizado no estudo foram inoculadas em meio NL líquido e, após 40 dias, os calos formados foram transferidos para o meio MS sólido para regeneração de plantas. Todas as plantas doadoras de anteras foram usadas na extração de DNA genômico e sete primers RAPD foram utilizados na geração de marcadores para a construção dos mapas de ligação dos retrocruzamentos estudados. A taxa de formação de calos variou de 2,27 a 3,36\% e a taxa de regeneração de plantas 1,38 a $1,82 \%$, não se diferenciando significativamente. Seis grupos de ligação foram obtidos, três em cada população. Um QTL com LOD 3,10 foi detectado para o caráter formação de calos na população Taipei 309 // BRS 7 "Taim" / Taipei 309. Nenhum QTL foi detectado para a característica regeneração de plantas.

Palavras-chave: subespécie indica, micrósporos, androgênese, calos, mapas de ligação.

\begin{abstract}
The low in vitro regeneration of some indica rice cultivars, limits the use of anther culture techniques as a tool to reduce the time for releasing new cultivars. The identification of genomic regions associated with callus formation and in vitro regeneration from anther culture, will facilitate selection of these traits through marker assisted techniques. Two backcross populations were used to study and map these traits, Taipei 309// BRS 7 "Taim"/ Taipei 309 (53 genotypes) and BRS 7 "Taim”// BRS 7 "Taim"/Taipei 309 (74 genotypes). Two hundred immature anthers, from each genotype used in this study, were inoculated in liquid NL medium for callus induction and, after 40 days, the formed callus were transferred to solid MS medium for plant regeneration. Each anther donor plant was used for DNA extraction and seven RAPD primers were used to assess genomic regions associated to callus formation and plant regeneration. As results, callus formation ranged from 2.27 up to $3.36 \%$ and plant regeneration ranged from 1.38 up to $1.82 \%$, no significant differences were observed. Six linkage groups were obtained, being three from each population. One QTL was detected associated to callus formation, with LOD score 3.10, in the population Taipei 309 // BRS 7 "Taim" / Taipei 309. No QTL association was detected to the trait plant regeneration.
\end{abstract}

Key words: indica subspecies, microspores, androgenese, callus, linkage map.

\footnotetext{
${ }^{1}$ Engenheiro Agrônomo, Mestrando do Programa de Pós-graduação em Agronomia (Fitomelhoramento) da Universidade Federal de Pelotas (UFPel), Pelotas-RS.

${ }^{2}$ Engenheiro Agrônomo, Dr, Professor do Departamento de Fitotecnia, da UFPel, Pelotas-RS.

${ }^{3}$ Engenheiro Agrônomo, PhD, Professor do Departamento de Fitotecnia, da UFPel, Campus Universitário, CP 354, 96001-970, Pelotas-RS. Email: acostol@terra.com.br. Autor para correspondência.

${ }^{4}$ Engenheiro Agrônomo, MsC, Doutorando do Programa de Pós-graduação em Agronomia (Fitomelhoramento) da UFPel, PelotasRS.

${ }^{5}$ Engenheiro Agrônomo, Mestrando do Programa de Pós-Graduação em Ciência e Tecnologia de Sementes, UFPel, Pelotas-RS.
} 


\section{INTRODUÇÃO}

A cultura do arroz assume papel fundamental na alimentação humana, fazendo parte da dieta básica de, pelo menos dois terços da população mundial, o que torna a espécie de grande interesse para a pesquisa, como produto estratégico para várias nações. Com um volume mundial anual de aproximadamente 585 milhões de toneladas, atualmente o arroz se constitui num modelo genético para todos os cereais por possuir um genoma comparativamente pequeno $(430 \mathrm{Mb})$, sintenia com os demais cereais, importância econômica e social e três projetos de sequenciamento parciais, além do rascunho do sequenciamento estrutural. Desta forma, sua utilização para estudos de função, ação e regulação de genes será cada vez mais intensa, necessitando neste caso, de protocolos bem estabelecidos de regeneração in vitro. Todas estas informações contribuirão para o incremento da eficiência do melhoramento do arroz e de outros cereais.

A obtenção de plantas duplo-haplóides é uma ferramenta biotecnológica promissora e sua principal vantagem reside no fato de que em apenas uma geração em laboratório poderão ser obtidas plantas $100 \%$ homozigotas, permitindo desta forma, um extraordinário ganho de tempo na fixação de caracteres de interesse e na otimização da seleção de constituições genéticas superiores (LENTINI et al., 1994). Os duplo-haplóides podem ser obtidos por via ginogênica ou por meio da androgênese. A androgênese consiste da regeneração in vitro de uma planta a partir de micrósporos imaturos - grão de pólen ou antera. Sob o enfoque do desenvolvimento, a cultura de micrósporos pode reverter o programa de desenvolvimento gametofítico para esporofítico, permitindo a geração de plantas haplóides.

Muitas das respostas morfogenéticas da formação de calos e regeneração in vitro de anteras são dependentes do genótipo, sendo que normalmente genótipos da subespécie japonica respondem melhor do que genótipos da subespécie indica (HU, 1985; RAINA, 1997). Em estudo comparativo entre as duas subespécies, a resposta para a cultura de anteras variou de 0 até $41 \%$ (MIAH et al., 1985). Embora exista variabilidade genética para os caracteres formação de calos e regeneração in vitro de anteras dentro de cada subespécie, poucos genótipos da subespécie indica apresentam alguma capacidade de regeneração in vitro. LENTINI et al. (1995) reportaram que apenas um genótipo, de um grupo de 35 genótipos da subespécie indica, respondeu à formação de calos a partir do cultivo de anteras.
Muito embora a expressão destes caracteres seja determinada geneticamente, existe grande dificuldade de transferência via cruzamentos devido à herança complexa que apresentam. Sob este enfoque, o cruzamento entre genótipos de subespécies diferentes, contrastantes para os caracteres, permitirá a geração de populações segregantes, e o acesso a estas com marcadores moleculares permitirá o mapeamento de locos controladores de caracteres quantitativos (QTLs) associados, possibilitando estudos da ação gênica, do número de genes envolvidos com a manifestação dos caracteres e uma seleção eficaz de genótipos portadores dos mesmos.

A técnica de marcadores moleculares do polimorfismo de DNA amplificado ao acaso (RAPD), amplamente utilizada em programas de melhoramento genético de plantas, mostrou ser uma ferramenta eficiente para estudos de variabilidade genética (YU \& NGUYEN, 1994) e mapeamento de genes de importância agronômica em arroz, como por exemplo, o gene $x a-13$, que confere resistência à ferrugem bacteriana (ZHANG et al., 1996).

Os objetivos deste trabalho foram estudar a regeneração in vitro de anteras de arroz irrigado dos cultivares BRS 7 “Taim” (spp indica) e Taipei 309 (spp japonica) e identificar marcadores moleculares ligados a QTLs responsáveis pela formação de calos e regeneração in vitro de anteras de arroz, mediante o mapeamento genético com marcadores moleculares RAPD.

\section{MATERIAL E MÉTODOS}

\section{Material Vegetal}

O presente estudo foi composto por duas populações de retrocruzamento obtidas a partir dos cruzamentos Taipei 309// BRS 7 "Taim"/Taipei 309 e BRS 7 "Taim”// BRS 7 “Taim”/Taipei 309, sendo as populações constituídas por 53 e 74 indivíduos, respectivamente. Os cultivares Taipei 309 (spp japonica) e BRS 7 "Taim" (spp indica) foram escolhidos pelo fato de serem contrastantes em relação ao caráter formação de calos em cultura in vitro, sendo que o cultivar Taipei 309 apresenta altas taxas de formação de calos, ao contrário do BRS 7 “Taim” (HU, 1985; RAINA, 1997).

Cultura de anteras e avaliação fenotípica das populações segregantes

A coleta das anteras imaturas foi realizada a cada dois dias, quando a distância entre a aurícula da folha bandeira e da penúltima folha encontrava-se entre quatro e seis centímetros, estádio em que o grão 
de pólen encontra-se uninucleado. Como prétratamento, as anteras foram submetidas à temperatura de $8^{\circ} \mathrm{C}$ por sete dias. Em seguida, foram tratadas com álcool $70 \%$ por um minuto, sob agitação constante, e logo após, em hipoclorito de sódio 0,4\% (princípio ativo), durante 15 minutos. Após a desinfestação, as anteras foram lavadas quatro vezes em água destilada onde permaneceram até serem transferidas para o meio de indução de calos NL líquido (LENTINI et al., 1994), suplementado com $5 \%(\mathrm{p} / \mathrm{v})$ de maltose. Para a indução de calos, 200 anteras de cada planta foram inoculadas no meio e acondicionadas no escuro em temperatura de $25^{\circ} \mathrm{C}$ por 40 dias.

Os calos formados foram transferidos para o meio de regeneração de plantas MS sólido, acrescido de $7 \mathrm{~g} \mathrm{~L}^{-1}$ de ágar e incubados à temperatura de $25^{\circ} \mathrm{C}$, com fotoperíodo de $16 \mathrm{~h}$ de luz (3000 lux de intensidade luminosa proveniente de lâmpadas fluorescentes brancas-frias). Após a regeneração, as plantas foram aclimatadas em casa-de-vegetação e cultivadas para a obtenção de sementes. O número de calos formados e o percentual de regeneração foram obtidos tanto para as cultivares BRS 7 “Taim” e Taipei 309 como para os indivíduos das populações segregantes.

O delineamento utilizado foi o inteiramente casualizado com diferentes números de repetições. Cada planta doadora de anteras foi considerada uma repetição.

Extração de DNA e análise de RAPD

O DNA genômico foi extraído pelo método CTAB (SAGHAI-MARROF et al., 1984), a partir das mesmas plantas que forneceram as anteras imaturas para os testes de formação de calos e regeneração de plantas in vitro. Para cada genótipo estudado, foram realizadas duas extrações independentes.

Após a extração, o DNA foi padronizado para uma concentração de $30 \mathrm{ng} \mathrm{mL}^{-1}$. A caracterização das populações, quanto às regiões genômicas responsáveis pela regeneração in vitro, foi realizada através do uso de marcadores de RAPD de acordo com o protocolo descrito por YANG et al. (1996). Foram testados 131 primers RAPD obtidos da "University of British Columbia, Inc.," e utilizados sete que amplificaram bandas polimórficas mais consistentes entre os pais, cujas seqüências são: i) UBC 075 GAGGTCCAGA; ii)UBC 308 AGCGGCTAGG; iii)UBC 312 ACGGCGTCAC; iv) UBC 313 ACGGCAGTGG; v) UBC319GTGGCCGCGC; vi) UBC 228ATGGCCTTAC; e, vii) UBC 329 GGTGGTTTCC. Cada marcador utilizado na construção dos mapas recebeu uma denominação própria que consiste no número do primer utilizado seguido da ordem do marcador no gel (onde foi utilizado o número 1 para o marcador de maior peso molecular e assim sucessivamente).

Construção dos mapas genéticos

Foram construídos dois mapas genéticos, um para o retrocruzamento Taipei 309// BRS 7 "Taim"/ Taipei 309 e outro para o retrocruzamento BRS 7 “Taim”// BRS 7 "Taim"/Taipei 309 utilizando-se o programa Mapmaker 3.0 (LINCOLN et al., 1992a). Primeiramente foi construído um esqueleto dos grupos de ligação utilizando como parâmetro o LOD 3,5 e a distância máxima de $25 \mathrm{cM}$, com as distâncias no mapa determinadas com o emprego da função Kosambi. Nesta primeira etapa, foi utilizado o comando "order", que é baseado na análise de multipontos para estabelecer a melhor ordem dos marcadores dentro de cada um dos grupos de ligação. Após o estabelecimento do esqueleto dos grupos de ligação, foram acrescidos mais marcadores aos mapas com a utilização do comando "try", sob LOD 3,0 e distância máxima de 30 cM.

Análise de QTLs

A análise de QTLs foi realizada utilizandose o programa Mapmaker QTL 1.1 (LINCOLN et al., 1992b), com um LOD 3,0, tendo sido utilizada a análise de intervalo. Foram utilizados os resultados de formação de calos e regeneração de plantas dos indivíduos das populações segregantes.

\section{RESULTADOS E DISCUSSÃO}

Índices de indução de calos e regeneração de plantas A taxa média de formação de calos variou de 2,27\% no parental BRS 7 "Taim" até 3,36\% no parental Taipei 309, sendo que as duas populações de retrocruzamento apresentaram taxas inferiores a do parental Taipei 309 e superiores a do parental BRS 7 "Taim". Para a regeneração de plantas, a taxa variou de $1,38 \%$ no parental BRS 7 "Taim" até $1,82 \%$ na população de retrocruzamento Taipei 309// BRS 7 “Taim”/Taipei 309 (Tabela 1).

Tanto os índices de indução de calos quanto os de regeneração de plantas in vitro, não diferiram significativamente entre os cultivares e as populações estudadas, pelo teste de Tukey a 5\% de significância. O desempenho similar pode ser decorrente da relativa baixa taxa de indução de calos e regeneração in vitro obtidos neste estudo. Segundo (RAINA, 1997), este baixo desempenho também pode ser decorrente de fatores como comprimento do dia, radiação solar e temperaturas noturnas às quais estavam submetidas às plantas doadoras de pólen. 
Tabela 1 - Médias de indução de calos e regeneração de plantas a partir de cultura in vitro de anteras de arroz (Oryza sativa L.). FAEM / UFPel, Pelotas, 2000

\begin{tabular}{lcc}
\hline População & Médias de calos formados (\%) & Médias de plantas regeneradas $(\%)$ \\
\hline BRS “Taim” & 2,27 a & 1,38 a \\
Taipei 309 & 3,36 a & 1,68 a \\
BRS 7 "Taim”// BRS 7 “Taim”/Taipei 309 & 2,31 a & 1,44 a \\
Taipei 309// BRS 7 "Taim”/Taipei 309 & $2,81 \mathrm{a}$ & $1,82 \mathrm{a}$ \\
\hline
\end{tabular}

*Médias seguidas da mesma letra não diferem estatisticamente pelo teste de Tukey a P>0,05\%.

Nenhum destes fatores foi mensurado durante o experimento, o que permitiria discussões mais avançadas. Os fatores associados a componentes do meio também podem ter influenciado os resultados, porém os meios utilizados já foram relatados anteriormente em outros estudos (LENTINI et al., 1995). As plantas doadoras de anteras foram mantidas em casa de vegetação durante todo o experimento. Plantas doadoras de anteras, mantidas em condições de campo, respondem de forma superior para os caracteres formação de calos e regeneração de plantas, do que plantas mantidas em casa-de-vegetação, como constatado em arroz (RAINA \& ZAPATA, 1997).

O estado fisiológico das plantas doadoras de anteras pode ser decisivo no desempenho dos protocolos de formação de calos e regeneração de plantas. Neste estudo, buscando uma resposta superior, as plantas doadoras de anteras foram semeadas tardiamente, pois em Brassica juncea, uma espécie recalcitrante, a eficiência do método foi aumentada de 3\% para 16\%, em função da semeadura tardia. Segundo AGARWAL \& BHOJWANI (1993), a semeadura tardia certamente atua como um fator de estresse para as plantas doadoras, podendo agir sobre diversos mecanismos que favoreçam a formação de calos e a regeneração de plantas. No entanto, segundo PETERS et al. (1999), baixa luminosidade e temperatura, podem afetar o desenvolvimento dos micrósporos. Portanto, neste estudo, a semeadura tardia pode ter afetado a viabilidade dos grãos de pólen e ao invés de contribuir para a eficiência do método, agiu de forma prejudicial. Um estudo sobre a fertilidade dos grãos de pólen permitiria maior inferência neste sentido. $\mathrm{O}$ efeito do estado fisiológico das plantas doadoras de anteras sobre a indução de calos e regeneração de plantas foi relatado em outros estudos (RAINA, 1997; FARUQUE et al., 1998).

Além das condições relativas à fisiologia das anteras, a constituição do meio de cultura afeta diretamente a eficiência dos protocolos de indução de calos e regeneração de plantas in vitro (BHOJWANI et al., 1999). Neste sentido, diversos trabalhos preconizaram a alteração da composição dos meios de cultura. Os principais constituintes que tiveram seu balanço alterado nos protocolos de cultura de anteras, buscando a obtenção de meios de cultura mais eficientes para o arroz, foram: sulfato de amônia [( $\left.\left.\mathrm{NH}_{4}\right)_{2} \mathrm{SO}_{4}\right]$ (RAINA, 1997), sulfato de magnésio $\left(\mathrm{MgSO}_{4}\right)$ e fosfato de potássio monobásico $\left(\mathrm{KH}_{2} \mathrm{PO}_{4}\right)$ (REDDY et al., 1985). No entanto, segundo PETERS et al. (1999), as condições ideais de cultivo são quase que específicas para cada genótipo. Neste sentido, a taxa de formação de calos e regeneração in vitro poderia ter sido incrementada mediante testes preliminares com diferentes meios de cultura.

O desempenho similar das duas populações de retrocruzamento contrasta com relatos de pesquisas anteriores, os quais destacaram desempenho superior de genótipos da subespécie japonica em relação a genótipos da subespécie indica (HU, 1985; MIAH et al., 1985; RAINA, 1997; FARUQUE et al., 1998). Além disso, PENG \& HODGES (1989) observaram considerável dissimilaridade genética entre as subespécies indica e japonica e comportamento diferenciado entre cultivares da subespécie indica, tanto para os caracteres indução de calos como para a regeneração de plantas in vitro.

\section{Mapeamento genético}

$\mathrm{Na}$ análise de marcadores moleculares 70 bandas foram avaliadas, das quais $40(57 \%)$ foram polimórficas em relação aos cultivares BRS 7 “Taim” e Taipei 309. Dentre as bandas polimórficas, 27 foram utilizadas na construção do mapa genético da população BRS 7 “Taim"// BRS 7 "Taim"/Taipei 309 e 29 na construção do mapa genético da população Taipei 309/ / BRS 7 "Taim"/Taipei 309. Deste total 16 bandas foram utilizadas na construção de ambos os mapas.

Dentre os 29 marcadores utilizados na construção do mapa genético da população Taipei 309/ / BRS 7 “Taim”/Taipei 309, 28 (97\%) foram mapeados em um dos 3 grupos de ligação obtidos (Tabela 2 e Figura 1-B). Somente um marcador não foi ligado a nenhum dos grupos de ligação. O mapa gerado cobriu 
Tabela 2- Número de marcadores, tamanho dos grupos de ligação e distância média entre marcadores dos mapas genéticos das populações de arroz (Oryza sativa L.), Taipei 309// BRS 7 “Taim”/Taipei 309 e BRS 7 "Taim”// BRS 7 “Taim”/Taipei 309. FAEM / UFPel, Pelotas, 2000

\begin{tabular}{|c|c|c|c|c|c|}
\hline \multirow{2}{*}{ Grupos de ligação } & \multicolumn{2}{|r|}{ Marcadores } & \multicolumn{2}{|c|}{ Tamanho } & \multirow{2}{*}{ Distância média (cM) } \\
\hline & Número & Proporção dos ligados (\%) & $\mathrm{cM}$ & Proporção do total (\%) & \\
\hline \multicolumn{6}{|c|}{ Taipei 309// BRS 7 “Taim”/Taipei 309} \\
\hline GL1 & 4 & 14,4 & 36,8 & 17,1 & 9,2 \\
\hline GL2 & 12 & 42,8 & 40,1 & 18,6 & 3,3 \\
\hline GL3 & 12 & 42,8 & 138,7 & 64,3 & 11,6 \\
\hline Total & 28 & 100 & 215,6 & 100 & \\
\hline Média & & & & & 7,7 \\
\hline \multicolumn{6}{|c|}{ BRS 7 “Taim”// BRS 7 “Taim”/Taipei 309} \\
\hline GL1 & 15 & 79,0 & 203,7 & 88,5 & 13,58 \\
\hline GL2 & 2 & 10,5 & 8,2 & 3,6 & 4,1 \\
\hline GL3 & 2 & 10,5 & 18,3 & 7,9 & 9,2 \\
\hline Total & 19 & 100 & 230,2 & 100 & \\
\hline Média & & & & & 12,1 \\
\hline
\end{tabular}

uma distância de 215,6 cM, e a proporção de marcadores ligados por grupo de ligação variou de $14,4 \%$ a $42,8 \%$. Os tamanhos dos grupos de ligação variaram de $36,8 \mathrm{cM}$ a $138,7 \mathrm{cM}$. Entre os grupos de ligação, a distância média entre os marcadores variou de 3,3 cM a 11,6 cM. A distância média entre os marcadores mapeados foi de 7,7 cM. Somente um intervalo entre dois marcadores apresentou uma distância superior a $30 \mathrm{cM}$, estando este intervalo no grupo de ligação GL3. Os grupos de ligação GL2 e GL3 foram os que apresentaram o maior número de marcadores ligados (12). Sete intervalos entre marcadores, quatro no GL2 e três no GL3, apresentaram distância de 0,0 cM.

Dentre os 27 marcadores utilizados na construção do mapa genético da população BRS 7 “Taim"// BRS 7 “Taim”/Taipei 309, 19 (70\%) foram mapeados em um dos 3 grupos de ligação obtidos (Tabela 2 e Figura 1-A). Oito marcadores não foram ligados a nenhum dos grupos de ligação obtidos. $\mathrm{O}$ mapa gerado cobriu uma distância de 230,2 cM, e a proporção de marcadores ligados por grupo de ligação variou de $10,5 \%$ a $79,0 \%$. Os tamanhos dos grupos de ligação variaram de 8,2 cM a 203,7 cM. Entre os grupos de ligação, a distância média entre os marcadores variou de $4,1 \mathrm{cM}$ a $13,58 \mathrm{cM}$. A distância média entre os marcadores mapeados foi de $12,1 \mathrm{cM}$. Somente um intervalo entre dois marcadores apresentou uma distância superior a 30 cM, estando este intervalo no grupo de ligação 1 (GL1). O grupo de ligação GL1 foi o que apresentou o maior número (15) de marcadores ligados (Tabela $2 \mathrm{e}$ Figura 1-A).
Os mapas genéticos obtidos no presente estudo podem ser considerados mapas básicos, uma vez que o número de marcadores mapeados e o tamanho das populações de mapeamento foram menores do que os utilizados em trabalhos anteriores (CAUSSE et al., 1994; HARUSHIMA et al., 1998). A impossibilidade de utilização de populações maiores deveu-se às dificuldades encontradas na regeneração de plantas.

A presença de 7 intervalos entre marcadores com distância de $0 \mathrm{cM}$, no mapa de ligação da população Taipei 309// BRS 7 "Taim"/Taipei 309 (Figura 1-B), pode ser decorrente do tamanho desta população (53 genótipos). Populações com poucos genótipos podem não permitir a observação da quebra de ligação entre os marcadores e a conseqüente determinação da distância entre estes. O tamanho adequado da população também depende do tipo de população, sendo que populações de retrocruzamento apresentam aproximadamente metade do conteúdo informativo do que populações $F_{2}$. A grande vantagem da utilização de populações $F_{2}$ é que os genótipos destas populações são formados por dois gametas que têm seus locos em desequilíbrio de ligação, e não por um único, como no caso dos genótipos obtidos por retrocruzamento.

\section{Detecção de QTL}

Após a realização da análise de QTL foi detectado a presença de um QTL associado à formação de calos no grupo de ligação GL2 da população Taipei 309// BRS 7 "Taim"/Taipei 309, no intervalo de 7,6 cM entre os marcadores R329.3 e R319.2 (Figura 1-B). O 


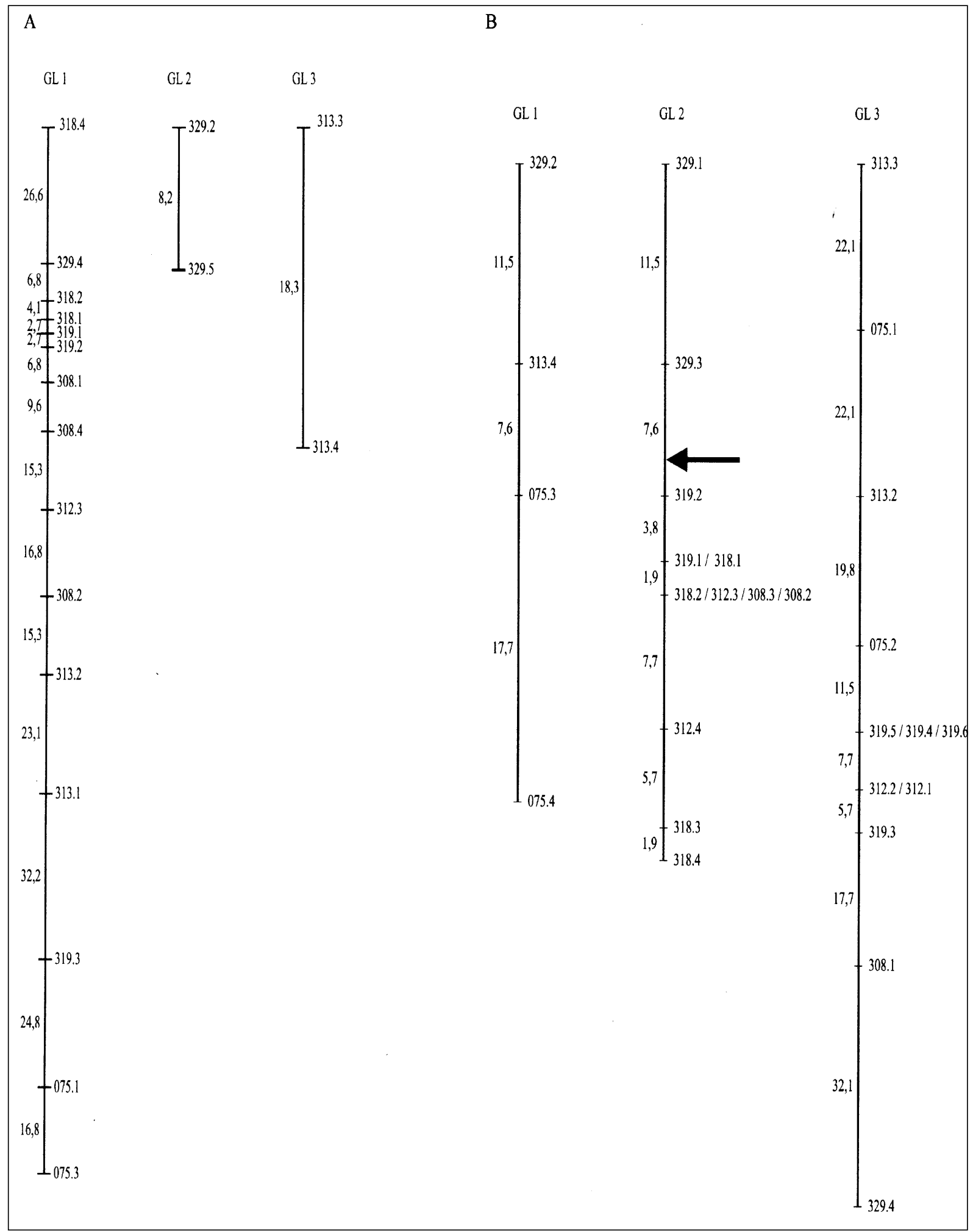

Figura 1- Grupos de ligação obtidos com as duas populações de retrocruzamento de arroz (Oryza sativa L.) (A - BRS 7 “Taim”// BRS 7 "Taim”/Taipei 309 e B - Taipei 309// BRS 7 "Taim”/Taipei 309). Os valores à esquerda indicam a distância entre os marcadores em cM e os à direita indicam o código do primer seguido da ordem do marcador no gel. A seta indica a localização do QTL associado ao caráter formação de calos. FAEM / UFPel, Pelotas, 2000.

Ciência Rural, v.34, n.5, set-out, 2004. 
QTL detectado explicou $26,7 \%$ da variação total da característica na população segregante, apresentou um pico de LOD de 3,10 e $2 \mathrm{cM}$ do marcador R319.2. O LOD encontrado é considerado significativo a $5 \%$ de propabilidade para a amplitude do genoma do arroz (OOIJEN, 1999), uma vez que é superior a 3,0 (valor mínimo significativo). No entanto, a análise de QTL não revelou a associação de nenhuma das regiões mapeadas com o caráter regeneração de plantas. Dois QTLs foram associados à regeneração de plantas a partir de anteras de arroz (HE et al.,1998). No entanto, neste estudo, QTLs para regeneração de plantas podem não ter sido detectados em função do baixo número de marcadores utilizados e mapeados, e do tamanho das populações. Além disso, a baixa taxa de formação de calos e regeneração de plantas, em função das condições fisiológicas das plantas doadoras e das condições do cultivo in vitro, podem ter contribuído para a não detecção de outros QTLs.

Uma vez que o mapa gerado não permitiu uma ampla cobertura do genoma da espécie é bem possível que regiões responsáveis pela manifestação dos caracteres não tenham sido acessadas. No entanto, o presente trabalho mostrou que é possível a detecção de QTLs associados a formação de calos a partir de anteras de arroz e que para a detecção de mais QTLs associados aos caracteres estudados, é necessária a utilização de protocolos eficientes na regeneração de plantas in vitro para a detecção com maior rigor das diferenças existentes, tanto entre os genitores quanto entre os indivíduos da população segregante, além da utilização de uma população segregante maior, para a garantia do aparecimento da maioria das classes fenotípicas de segregação dos genes.

A comparação dos mapas obtidos indicou a correspondência dos mesmos e embora o QTL só possa ser medido no mapa B (Figura 1), devido ao fato da segregação do caráter ocorrer somente nesta população, algumas inferências podem ser feitas. $\mathrm{O}$ grupo 1 do mapa A correspondeu ao grupo 3 do mapa $\mathrm{B}$, havendo uma variação da distância de 44,7 cM entre os marcadores 313.2 e 319.3 , para 55,3 cM. Outras comparações podem auxiliar o agrupamento dos dois mapas ou facilitar a saturação da região do QTL, por exemplo, ao redor do marcador 319.2, foi possível identificar no mapa A o marcador $319.1(2,7 \mathrm{cM})$; o marcador $318.1(5,4 \mathrm{cM})$ e o marcador $308.1(6,8 \mathrm{cM})$, que dependendo da posição proximal ou distal do QTL, podem ser mais informativos. A comparação sugere que a posição do QTL seja coincidente com o marcador 308.1, uma vez que os outros marcadores localizaramse distalmente ao marcador 319.2, no grupo de ligação GL2 do mapa B (Figura 1). Além disso, pode-se observar que na região que flanqueia o QTL no grupo de ligação GL2 do mapa B, houve uma concentração de marcadores $(319.2,319.1,318.1,312.3$ e 318.2$)$ distribuídos em 5,7 cM, a qual pode ser observada no grupo de ligação GL1 do mapa A numa região de 9,5 cM. No entanto, a ordem destes marcadores não foi mantida integralmente. Esta pequena distância detectada entre os marcadores em ambos os mapas pode ser decorrente do pequeno número de indivíduos genotipados em ambas as populações. O desenvolvimento de novas populações e a inclusão de microsatélites permitirá a saturação do mapa ao redor do QTL encontrado. Em conclusão, os resultados do presente trabalho mostram que pelo menos um QTL para formação de calos foi encontrado e pode ser usado em programas de seleção assistida, visto que dois marcadores (329.3 e 319.2) flanqueiam o referido QTL.

\section{AGRADECIMENTOS}

Os autores agradecem ao CNPq, à CAPES e à FAPERGS, a concessão de financiamentos, bolsas de estudo e de produtividade em pesquisa.

\section{REFERÊNCIAS BIBLIOGRÁFICAS}

AGARWAL, P.K.; BHOJWANI, S.S. Enhanced microspore embryogenesis and plant regeneration in anther cultures of Brassica juncea cv. PR-45. Euphytica, Dordrecht, v.70, n.3, p.191-196, 1993

BHOJWANI, S.S.; SOH, W.Y.; PANDE, H Morphogenesis in haploid cell cultures. In: SOH, W.Y.; BHOJWANI, S.S. Morphogenesis in plant tissue cultures. Dordrecht : Kluwer Academic Publishers, 1999. Cap.3, p.70-104.

CAUSSE, M.A. et al. Saturated molecular map of the rice genome based on an interspecific backcross population. Genetics, Bethesda, v.138, n.4, p.1251-1274, 1994.

FARUQUE, M.O. et al. Variations in green plant regeneration response from anthers of indica rice and their hybrids with japonica cv. Taipei 309. Plant Cell, Tissue and Organ Culture, Dordrecht, v.54, n.3, p.191-195, 1998.

HARUSHIMA, Y. et al. A high-density rice genetic linkage map with 2275 markers using a single $F_{2}$ population. Genetics, Bethesda, v.148, n.1, p.479-494, 1998.

HE, P. et al. Analysis of quantitative trait loci which contribute to anther culturability in rice (Oryza sativa L.). Molecular Breeding, Dordrecht, v.4, n.2, p.165-172, 1998.

HU, H. Use of haploids for crop improvement in China. Genetic Manipulation Crops Newsletter, Berlin, v.1, n.1, p.11-23, 1985.

LENTINI, Z. et al. Mejoramiento del arroz con cultivo de anteras: aplicaciones en el desarrollo de germoplasma 
adaptado a ecosistemas latinoamericanos y el Caribe. Cali: CIAT, 1994. 79p.

LENTINI, Z. et al. Androgenesis of highly recalcitrant rice genotypes with maltose and silver nitrate. Plant Science, Clare, v.110, n.1, p.127-138, 1995.

LINCOLN, S.; DALY, M.; LANDER, E.S. Constructing genetic maps with MAPMAKER/EXP 3.0. 3.ed. Cambridge: Whitehead Institute Technical Report, 1992a. 97p.

LINCOLN, S.; DALY, M.; LANDER, E.S. Mapping genes controlling quantitative traits with MAPMAKER/QTL 1.1. Cambridge : Whitehead Institute Technical Report. 1992b. 73p.

MIAH, M.A.A.; EARLE, E.D.; KHUSH, G.S. Inheritance of callus formation ability in anther cultures of rice, Oryza sativa L. Theoretical and Applied Genetics, Heidelberg, v.70, n.2, p.113-116, 1985.

OOIJEN, J.W. LOD significance thresholds for QTL analysis in experimental populations of diploid species. Heredity, London, v.83, n.5, p.613-624, 1999.

PENG, J.; HODGES, T.K. Genetic analysis of plant regeneration in rice (Oryza sativa L.). Vitro Cellular \& Developmental Biology, Las Cruces, v.25, n.1, p.91-94, 1989.

PETERS, J.A.; BOBROWSKI, V.L.; ROSINHA, G.M.S. Produção de haplóides e duplo-haplóides. In: TORRES, A.C.; CALDAS, L.S.; BUSO, J.A. Cultura de tecidos e transformação genética de plantas. Brasília : EMBRAPASPI / EMBRAPA-CNPH, 1999. Cap.3, p.569-611.
RAINA, S.K. Doubled haploid breeding in cereals. Plant Breeding Reviews, v.15, n.1, p.141-186, 1997.

RAINA, S.K.; ZAPATA, F.J. Enhanced anther culture efficiency of indica rice (Oryza sativa L.) through modification of the culture media. Plant Breeding, Berlin, v.116, n.4, p.305-315, 1997.

REDDY, V.S.; LEELAVATHI, S.; SEN, S.K. Influence of genotype and culture medium on microspore callus induction and green plant regeneration in anthers of Oryza sativa. Plant Physiology, Rockville, v.63, n.2, p.309$314,1985$.

SAGHAI-MARROF, M.A. et al. Ribosomal DNA spacer length polymorphism in barley: Mendelian inheritance, chromosome location and population dynamics. Proceedings of the national academy of sciences of the U.S.A, v.89, n.2, p.1477-1481, 1984.

YANG, W. et al. Comparison of DNA marker technologies in characterizing plant genome diversity: Variability in chinese sorghums. Crop Science, Madison, v.36, n.6, p.1669-1676, 1996 .

YU, L.X.; NGUYEN, H.T. Genetic variation detected with rapd markers among upland and lowland Rice cultivars (Oryza sativa L.). Theoretical and Applied Genetics, Heidelberg, v.87, n.6, p.668-672, 1994.

ZHANG, G. et al. RAPD and RFLP mapping of the bacterial blight resistance gene $x a-13$ in rice. Theoretical and Applied Genetics, Heidelberg, v.93, n.1-2, p.65-70, 1996. 